\title{
42 THEORY AND ACTION FOR EMANCIPATION: Elements of a Critical Realist Approach
}

\author{
Melanie Wilson \\ Anita Greenhill \\ Manchester School of Management, UMIST
}

\begin{abstract}
Adopting a non-Habermasian critical realist position, this paper seeks to outline some key elements of a realist ontology, on the one hand, and a radical critical stance on the other. The relationship of critical realism to positivism and interpretivism is described, and the case for methodological pluralism made. The elements of realism described are connection of the particular with general, contribution to knowledge, and construction of alternatives. The critical aims entail a commitment to emancipation, a focus on issues of equality and inequality, a questioning of the status quo, and a challenging of ideology. One key conclusion for practice concerns the alliances for researchers with less conservative members of organizations in order to avoid compromise on emancipatory aims. The contribution of the paper is summarized in a concluding table.
\end{abstract}

Keywords: Critical realism, methodological pluralism, emancipation

\section{INTRODUCTION}

This short paper delineates some key elements that constitute a critical realist approach to Information Systems research. Contending that there are options beyond the interpretive-positivist dichotomy and that methodological pluralism is feasible, we supplement the extant IS critical literature. Generally speaking, critical tends to imply critical social theory. Thus, we refer to the body of writing in this more established IS trend. Our contribution is provided by drawing on research in the social sciences concerning the validity of a critical realist approach to understanding phenomena within organizations. Within IS research, Dobson (2001) has indicated the potential of critical 
realism, Mingers (2001) has made the case for strong pluralism based on a realist ontology, and a guide to the use of critical realism has been well described by Carlsson (2004). Further to this, the paper is distinguished by a preference for materialist, radical writing on organizations, such as Braverman (1974) based on a Marxian approach (as opposed to the more popular Habermasian writings, based on a more idealist, Hegelian approach).

The choice of realist elements included is guided by an implicit polemic against a flat treatment of the agency structure dimension (Carlsson 2004). One of the main advantages of the adoption of a realist ontology is that it allows for the feasibility of methodological pluralism (Mingers 2001), guided by the principle that the choice of methods employed should be decided by the nature of the object of study. Underpinning the critical standpoint is a neo-humanism (Hirschheim and Klein 1989) with a radical twist. The critical elements selected serve to underline the exigency for emancipatory action. In conclusion, the implications of the approach for IS research are sketched in a summary table. Next, we pave the way for later sections by situating critical realism in relation to the positivist-interpretivist debate.

\section{CRITICAL REALISM, POSITIVISM, AND INTERPRETIVISM}

Critical realism is an attempt to transcend the bi-polar opposition between positivism and interpretivism (Outhwaite 1983). Evidently, research needs an amount of rigor to be of value and realism appeals to notions of scientific method and objectivity. The term critical denotes a challenge to the orthodoxy of accounts which reinforce the status quo of (unequal) power relations in organizations. While sharing many of the fundamental assumptions of the Habermasian-inspired critical social theory (Ngwenyama 1991), we favor a Marxian, non-Hegelain understanding of how radical emancipatory change in the status quo can occur. The implications of this dissimilarity must be debated elsewhere. Suffice to mention here that our approach is skeptical of the possibility of overcoming conflict in organizations, and reluctant to extend the acceptance of the socially constructed nature of knowledge to the point of extreme relativism.

The increased popularity in using critical and social constructivist approaches to study technology in IS helps in "demystifying technological imperatives and managerial rationalism justifying a particular IS design" (Cecez-Kecmanovic 2001, p. 141). Such perspectives have raised issues concerning the ontological and epistemological assumptions implied by an acknowledgment of the role of culture and language in framing our knowledge of the world. One problem faced by researchers stems from the commonly held assumption that there are two basic perspectives on offer,

either the world is objectively and unproblematically available...or it is not knowable objectively at all; and, in the place of claims to objectivity, we find only the idea that what is known is merely the product of discourse (Ackroyd and Fleetwood 2000, p. 4).

In response, realists have argued that a dualistic or analytic ontology is necessary for studying organization and management, which asserts the reality of belief systems 
and cultures as elements that should feature in realist explanations (Reed 2000). Thus, conceptualizing the attitudes, values, and cultures of people will be central. However, realists do not accept that the world is entirely constituted by the discursive acts of people: unobservable social structures (mechanisms, relations, powers, rules, resources, institutions, technology) must also be taken into account. Hence, in critical realism, the view of social reality is materialist and structuralist in nature, with reality existing independently from the observer. Further, reality is ordered and thus open to explanation. With this realist ontology it follows that a critical realist approach, to an extent, accepts the applicability of scientific principles unearthed in the natural science of the social subject, while simultaneously adopting the position that there are fundamental differences between natural and social phenomena (Ngwenyama 1991).

\section{WHAT CONSTITUTES A REALIST APPROACH?}

In this section we detail elements that form part of the realist side of the critical realist approach.

\subsection{Connection of Particular with General}

Critical realism has a predilection to connect the particular with the general. This entails an examination of structures and mechanisms, such as stratification of work. An important assumption here is that IS are part of social phenomena and therefore must be viewed as open systems (Mingers 2000). The focus is on the mechanisms operating in society that are required to be in place in order for a certain set of circumstances to exist. Laws expressing the tendencies of things are a credible subject of enquiry in critical realism (Blaikie 1986, p. 8). hus, explanatory mechanisms are postulated and the task of research is to try to demonstrate their existence. However, for realists, causation is not understood on the model of regular successions of events (Sayer 2000). While regularity is expected, consistent regularities are unlikely as they occur only in closed systems. In addition, we may want to explain why a certain mechanism exists and so we will engage in exploring the nature of the structure or object which possesses that mechanism or power.

\subsection{Contribution to Knowledge: Ontology and Epistemology}

In terms of ontology, and the contribution of research to knowledge, realism assumes that what exists can be discovered (Ackroyd and Fleetwood 2000). An associated assertion is that the nature of the world being investigated dictates the appropriate methods for that investigation. In common with others (Orlikowski and Baroudi 1991), a plurality of research perspectives is recommended. However, while researchers have advocated the integration of positivist and interpretivist approaches (Lee 1991; Trauth and Jessup 2000) and the integration of case study with survey research methods (Gable 1994), or combining qualitative and quantitative methods (Kaplan and Douchon 1988), 
the underlying philosophy and issues of ontology are not addressed (Carlsson 2004). One exception is Mingers (2001) and his advocacy for strong pluralism.

\subsection{Construction of Alternatives}

The promotion ofalternatives is highly dependent on the critical points made below. The argument is that, if by our research and writing we make apparent how our own acts and those of others are implicated in the reproduction of social structures and relations that stand in the way of emancipation, then we are potentially in a position to consider alternative structures and solutions (Collier 1998).

\section{WHAT IS CRITICAL?}

Having outlined the realist characteristics of a critical realist approach, we now construct the critical aspect.

\subsection{Question Status Quo}

In questioning the assumed status quo in social interaction, critical realism assumes that everyday life has superficial and often conflictual aspects in operation. In relation to IS in organizations, we would be aware and critical of capitalism and the labor process. Marx drew a central distinction between essential relations and surface appearance (Pratten 2000). In building on Marx's insights, the tradition initiated by Braverman (1974) inaugurated a radical critique of the use of technology in organizations because of the potential of increased exploitation of workers. For the IS researcher, this implies an examination of the construction and use of technology to further increase the process of exploitation on the part of management and at the expense of employees. ${ }^{1}$

\subsection{Challenge to Ideology}

Braverman's (1974) radical approach implicitly challenges views of organizations which do not seek to explore the contradictions emanating from their conflictual nature. A critical realist approach challenges accounts of the status quo and aims to deconstruct dominant ideology. Two notions to be criticized here are managerialism (for increasing productivity and curtailing worker resistance) and technological determinism (for excluding human agency and not examining social and organizational contexts [Lopez and Potter 2001]).

While interpretivism offers us the possibility for capturing such complex, dynamic, social phenomena, it will be vulnerable to those criticisms aimed at Habermasian approaches, namely that it does not examine the (material) conditions which give rise

${ }^{1}$ Maru and Woodford (2001) argue that in some critical approaches, the focus on emancipation has been relegated due to a concentration on pluralism. This, claims Dobson (2003), is a logical outcome of the epistemological focus of the underlying critical theory of Habermas. 
to certain meanings and experiences, that it neglects to clarify historical change; unintended consequences of actions go unexplained, and that it ignores the structural conflicts and contradictions endemic to social systems (Hollis 1994). Further, interpretivism does not explicitly contain the notion of "non-corrigible accounts," constraining our ability to criticize actors' views of the world (Blaikie 1986). Critical realism, by comparison, presents the possibility of ideological error (Lopez and Potter 2001) since it allows for the notion of false beliefs and consciousness.

\subsection{Focus on Equality and Inequality}

Critical approaches maintain a focus on issues of equality and inequality. Critical realist researchers have recourse to the dialectic of equity: "the principle of sufficient practical reason states that there must be ground for difference. If there is no such ground then we are rationally impelled to remove them" (Bhaskar 1998, p. 676). In IS research we would be looking at patterns and conditions of employment to highlight areas of inequality, since the labor market is not only a reflection of inequalities in broader society, but rather plays a part in the generation of inequality (Peck 2000).

\subsection{Commitment to Emancipation}

Finally, and perhaps most importantly, a critical approach implies a commitment to contribute to changing the world for the better and for the creation of structures that are wanted, needed, or generally emancipatory (Hollis 1994; Orlikowski and Baroudi 1991). Revealing the way things are is a necessary step to demonstrate the place of human acts in the "reproduction of social structures and relations that stand in the way of emancipation" (Ackroyd and Fleetwood 2000, p. 23), thereby enabling the suggestion of alternative structures where genuine human flourishing can develop. Critical realism seeks ways of transforming asymmetric relations and calls for action to mobilize research: to act to prevent degeneration of equity, and to improve the situation. This would imply we do not support IS that lead to increased exploitation and a worsening of extant inequalities. In this regard, Mingers (2001) identifies the restrictive nature of alliances with managers who can determine what the researcher does, setting the scope and boundaries of investigation. One solution to this quandary of compromised research is the creation of alternative alliances with agencies concerned with employee welfare, such as trades unions.

\section{CONCLUSION}

This paper contributes to existing critical research in IS by describing elements of a critical realist approach for exploring an IS phenomenon from a more radical tendency as represented in labor process writings. The significance of this for IS is summarized in Table 1. 
Table 1. Summary of Critical Realist Elements in Relation to IS Research

\begin{tabular}{|c|c|c|}
\hline & Area of Interest & Example Target Areas of Concern \\
\hline \multicolumn{3}{|c|}{ Realism Element } \\
\hline $\begin{array}{l}\text { Connecting } \\
\text { particular to } \\
\text { general }\end{array}$ & $\begin{array}{l}\text { Existing social structures and } \\
\text { mechanisms. }\end{array}$ & $\begin{array}{l}\text { Stratification of work, impact of } \\
\text { technology on work practices, impact } \\
\text { of IT/IS on workers. }\end{array}$ \\
\hline $\begin{array}{l}\text { Contribution } \\
\text { to knowledge }\end{array}$ & $\begin{array}{l}\text { Nature of phenomenon and } \\
\text { appropriate method for } \\
\text { investigation. }\end{array}$ & $\begin{array}{l}\text { Quantitative analysis for examination } \\
\text { of wages, conditions, patterns of } \\
\text { employment. } \\
\text { Qualitative investigation of meaning } \\
\text { of work. }\end{array}$ \\
\hline $\begin{array}{l}\text { Construction } \\
\text { of alternatives }\end{array}$ & $\begin{array}{l}\text { Alternative structures and } \\
\text { solutions. } \\
\text { Alternative research questions, } \\
\text { priorities and aims. }\end{array}$ & $\begin{array}{l}\text { Social measures to alleviate worst of } \\
\text { alienation. } \\
\text { New perspectives and research foci } \\
\text { generated via alliances with } \\
\text { employee-centered agencies. }\end{array}$ \\
\hline \multicolumn{3}{|c|}{ Critical Element } \\
\hline $\begin{array}{l}\text { Questioning } \\
\text { status quo }\end{array}$ & $\begin{array}{l}\text { Development and use of IS to } \\
\text { increase exploitation of } \\
\text { employees. } \\
\text { Partnership with nonmanagerial } \\
\text { sponsors in defense of employee } \\
\text { conditions. }\end{array}$ & $\begin{array}{l}\text { Extension of working day; deteriora- } \\
\text { tion in working conditions; routini- } \\
\text { zation of tasks. } \\
\text { Possibilities for collective repre- } \\
\text { sentation. }\end{array}$ \\
\hline $\begin{array}{l}\text { Deconstruct } \\
\text { dominant } \\
\text { ideology }\end{array}$ & $\begin{array}{l}\text { Social and organizational context } \\
\text { of IS examined to challenge mana- } \\
\text { gerialism and technological } \\
\text { determinism. } \\
\text { Equating technical with social } \\
\text { progress in relation to IS } \\
\text { phenomenon. }\end{array}$ & $\begin{array}{l}\text { (Non-)valuing of employees by } \\
\text { managers. } \\
\text { Increased/decreased conflict between } \\
\text { work and home. } \\
\text { Examination of talk of flexibility } \\
\text { against lower job security. }\end{array}$ \\
\hline $\begin{array}{l}\text { Equality and } \\
\text { Inequality }\end{array}$ & $\begin{array}{l}\text { Areas of inequality of treatment } \\
\text { and conditions. } \\
\text { Patterns of work in relation to use } \\
\text { of IS. }\end{array}$ & $\begin{array}{l}\text { Access and experience of IS by } \\
\text { employees different from managers. } \\
\text { Propensity to part-time, degraded } \\
\text { work. }\end{array}$ \\
\hline Emancipation & $\begin{array}{l}\text { Ways to transform asymmetric } \\
\text { relations. } \\
\text { Mobilization of research to } \\
\text { prevent degeneration of equity. }\end{array}$ & $\begin{array}{l}\text { Examination of chances for } \\
\text { development or promotion, increased } \\
\text { division of labor. } \\
\text { Assemble policy making groups for } \\
\text { dissemination of research }\end{array}$ \\
\hline
\end{tabular}

\section{REFERENCES}

Ackroyd, S., and Fleetwood, S. "Realism in Contemporary Organization and Management Studies," in S. Ackroyd and S. Fleetwood (Eds.), Realist Perspectives on Management and Organizations, London: Routledge, 2000, pp. 1-25.

Bhaskar, R. "Dialectical Critical Realism and Ethics," in M. Archer, R. Bhaskar, A. Collier, T. Lawson and A. Norrie (Eds.), Critical Realism: Essential Readings, London: Routledge, 1998, pp. 641-687. 
Blaikie, N. Approaches to Social Enquiry. Cambridge: Polity Press, 1986.

Braverman, H. Labor and Monopoly Capital: The Degradation of Work in the Twentieth Century, New York: Monthly Press Review, 1974.

Carlsson, S. A. "Using Critical Realism in IS Research," in M. E. Whitman and A. B. Woszcynski (Eds.), The Handbook of Information Systems Research, Hershey, PA: Idea Group Publishing, 2004, pp. 323-338.

Cecez-Kecmanovic, D. "Doing Critical IS Research: The Question of Methodology," in E. M. Trauth (Ed.), Qualitative Research in IS: Issues and Trends, Hershey, PA: Idea Group Publishing, 2001, pp. 141-162.

Collier, A. "Explanation and Emancipation," in M. Archer, R. Bhaskar, A. Collier, T. Lawson and A. Norrie (Eds.), Critical Realism: Essential Readings, London: Routledge, 1998, pp. 444-472.

Dobson, P. J. "The Philosophy of Critical Realism: An Opportunity for Information Systems Research," Information Systems Frontier (3:2), 2001, pp. 199-201.

Dobson, P. J. "The SoSM Revisited: A Critical Realist Perspective," in J. J. Cano (Ed.), Critical Reflections on Information Systems: A Systemic Approach, Hershey PA: Idea Group Publishing, 2003, pp. 122-135.

Gable, G. "Integrating Case Study and Survey Research Methods: An Example in Information Systems," European Journal of Information Systems (3:2), 1994, pp. 112-126.

Hirschheim, R., and Klein, H. K. "Four Paradigms of Information Systems Development," Communications of the ACM (32:10), 1989, pp. 1199-1216.

Hollis, M. The Philosophy of Social Science: An Introduction, Cambridge: Cambridge University Press, 1994.

Kaplan, B., and Douchon, D. "Combining Qualitative and Quantitative Methods in Information Systems Research: A Case Study," MIS Quarterly (12:4), December 1988, pp. 571-586.

Lee, A. S. "Integrating Positivist and Interpretive Approaches to Organizational Research," Organization Science (2:4), 1991, pp. 342-365.

Lopez, J., and Potter, G. (Eds.). After Postmodernism: An Introduction to Critical Realism, London: The Athlone Press, 2001.

Maru, Y. T., and Woodford, K. "Enhancing Emancipatory Systems Methodologies for Sustainable Development," Systemic Practice and Action Research (14:1), 2001, pp. 61 -77.

Mingers, J. "Combining IS Research Methods: Towards a Pluralist Methodology," Information Systems Research (12:3), 2001, pp. 240-259.

Mingers, J. "An Idea Ahead of its Time: The History and Development of Soft Systems Methodology," Systemic Practice and Action Research (13:6), 2000, pp. 733-755.

Ngwenyama, O. K. "The Critical Social Theory Approach to Information Systems: Problems and Challenges," in H.-E. Nissen, H. K. Klein, and R. A. Hirschheim (Eds.), Information Systems Research: Contemporary Approaches and Emergent Traditions, Amsterdam: North-Holland, 1991, pp. 276-280.

Orlikowski, W. J., and Baroudi, J. J. "Studying IT in Organizations: Research Approaches and Assumptions," Information Systems Research (2:1), 1991, pp. 1-28.

Outhwaite, W. "Towards a Realist Perspective," in G. Morgan (Ed.), BeyondMethod: Strategies for Social Research, London: Sage Publications, 1983, pp. 321-330.

Peck, J. "Structuring the :abor Market: A Segmentation Approach," in S. Ackroyd and S. Fleetwood (Eds.), Realist Perspectives on Management and Organizations, London: Routledge, 2000, pp. 220-244.

Pratten, S. "Structure, Agency and Marx's Analysis of the Labor Process," in S. Ackroyd and S. Fleetwood (Eds.), Realist Perspectives on Management and Organizations, London: Routledge, 2000, pp. 109-137.

Reed, M. I. "In Praise of Duality and Dualism: Rethinking Agency and Structure in Organizational Analysis," Organizations Studies (18:1), 2000, pp. 21-42. 
Sayer, A. Realism and Social Science, London: Sage Publications, 2000.

Trauth, E., and Jessup, L. "Understanding Computer-Mediated Discussions: Positivist and Interpretive Analyses of Group Support System Use," MIS Quarterly (24:1), 2000, pp. 43-79.

\section{ABOUT THE AUTHORS}

Melanie Wilson is a lecturer in Information Systems and Technology Management at Manchester School of Management, UMIST. Generally her research interests lie in the area of social and organizational aspects of Information Systems. Adopting social shaping and critical approaches to IS research, specific topics include gender success/failure, ICT enabled work practices. Melanie can be contacted Melanie.wilson@umist.ac.uk.

Anita Greenhill is a lecturer in Information Systems and Technology Management at Manchester School of Management, UMIST. Anita's research interests include social, cultural, and organizational aspects of Information Systems. Adopting social shaping and critical approaches to IS research, she researches a diversity of topics including ICT enabled work practices, space, virtuality, Web information systems development, and gender. Anita can be contacted at A.Greenhill@umist.ac.uk. 